\title{
Speleotourism potential and tourist experience in Resava cave
}

\author{
Aleksandar Antić ${ }^{*}$ \\ ${ }^{1}$ MSc student, University of Novi Sad, Faculty of Sciences, Department of Geography, \\ Tourism and Hotel Management
}

\begin{abstract}
Resava Cave is a very old cave in Eastern Serbia, authentic and popular, with special geological and geomorphological features that are excellent representatives of the area's geodiversity. Most of the speleotourism and geotourism potential of this geosite still remains unlocked. This paper provides an analysis of the tourist potential and tourist experience for speleotourism development of Resava Cave. The aim was to explore the speleotourism potential of Resava cave and to determine and compare tourist experience while visiting this cave. The research includes a a survey of tourists who visited Resava Cave during the month of May, 2018. Each respondent was asked a total of sixteen questions related to their social-demographic profile, the evaluation of certain speleotourist indicators and the tourists' personal attitude to their experience in the cave. Results of the paper have shown that the tourism potential is very high and experiences are diverse, but some of them are more present than the others.
\end{abstract}

Keywords: speleotourism, Resava cave, tourism potential, tourist experience JEL classification: L83, Z32

\section{Speleoturistički potencijali i iskustva turista u Resavskoj pećini}

Sažetak: Resavska pećina je jedinstvena, popularna i veoma stara pećina u istočnoj Srbiji, sa posebnim geološkim i geomorfološkim karakteristikama, koji su odlični predstavnici geodiverziteta ovog područja. Speleoturizam i potencijal geoturizma ovog geolokaliteta ostaju neotkriveni. U ovom radu je sprovedena analiza turističkih potencijala i iskustva turista za razvoj speleoturizma u Resavskoj pećini. Cilj je istražiti potencijal za razvoj speleoturizma ove pećine i odrediti i uporediti iskustva turista tokom posete Resavske pećine. Istraživanje je realizovano putem anketiranja turista koji su posetili pećinu tokom maja meseca 2018. godine. Svakom ispitaniku je postavljeno po šesnaest pitanja koja se odnose na njihov socio-demografski profil, evaluaciju određenih speleoturističkih indikatora i izražavanje ličnog stava o turističkom iskustvu u pećini. Rezultati rada pokazali su da je turistički potencijal veoma visok i da su iskustva različita, ali neka od njih su više zastupljena od drugih.

Ključne reči: speleoturizam, Resavska pećina, turistički potencijal, iskustvo turista JEL klasifikacija: L83, Z32 


\section{Introduction}

Tourism in eastern Serbia has a significant potential for the development of local and regional economies. The karst regions and caves in particular hold exceptional value in this region and with their distinctiveness, they are potential indicators for the development of several forms of tourism in this area, including speleoturism, geotourism, adventure and excursion tourism etc. Considering that Resava Cave is one of the most popular in Serbia, it is necessary to explore the tourist experience. Only then can we know which types of speleotourism need to be more developed in the tourist offer of Resava cave.

In addition to the fact that this cave has great popularity among the recreation, nature and cave enthusiasts, this speleological geosite has a significant geological and geomorphological processes and unique speleomorphological units that are of great importance for speleology and development of science in general. Numerous cave figures are very attractive for visitors and can be a crucial reason for visiting. It is known that many tourists consider the caves to be mystical and dark places. Therefore, it is necessary to provide adequate infrastructure, technical equipment and guidance service.

The main goal of this paper is to explore the speleotourism potential of Resava Cave and to determine and compare the experiences of the tourists who visited the cave. The research included a survey of tourists who visited Resava cave during 2018. The respondents provided answers to a total of sixteen questions, which included evaluating certain speleotourist indicators and expressing a personal attitude about their experience in the cave. The results of the analysis should provide information about the speleotourism potential and tourist experience of Resava Cave. The survey was conducted with the topic „Research on tourist attitudes and experience in Resava Cave".

\section{Literature review}

Many aspects of nature have a great potential for tourism. Among them there are mountains, canyons, islands, beaches, rivers and waterfalls, as well as wildlife and vegetation. In this vast panorama of options, caves stand out due to their unique features, both scientific and aesthetic, resulting in a high degree of attractiveness. The management of tourist related activities, in protected cave areas, requires a solid and scientifically based knowledge of the environment, with special emphasis on the limits of the resilience of the geo and ecosystems directly and indirectly affected by such activities (Lobo et al., 2013). A stony limestone region known as Kras on the border region of Slovenia and Italy was the place where karst and caves were first scientifically studied (Gams, 2003).

Caves are also called speleological objects and tourism based on them is called speleotourism or cave tourism (Knežević \& Grbac-Žiković, 2011). Cave tourism is a fairly recent name given to tourism that involves speleological structures. As a form of special interest tourism, cave tourism can be found in the tourism offerings of countries in which carbonate terrain is widespread. Because of some of the features of its offering (labyrinths, narrow passages, high humidity and the lack of natural light), this form of tourism has been included in adventure tourism (National Caves Association).

A part of speleotourism, the background of geotourism may also be related to caves (Cardozo Moreira \& Neto de Carvalho, 2013). Geotourism represents a sustainable form of tourism with a primary focus on experiencing the earth's geological features and creating geotourism product. Geotourism is also protecting geoheritage, building communities and promoting geological heritage (Dowling, 2013). 
Caves were the earliest tourist attractions, and nowadays one of the most appreciated geotourism destinations in the world (Anderson, 2010). Many of the existing World Heritage properties include outstanding caves with rich and varied speleothem decoration, that can be crucial indicators for speleotourism development. Most caves are decorated with crystalline deposits such as stalactites and stalagmites (collectively known as speleothems) (Williams, 2008).

The economic perspective of speleotourism has great potential. The profits derived directly and indirectly from the touristic exploitation of caves can acquire substantial importance at local level (Pulido-Bosch et al., 1997). However, the lack of regulation of the visits, an adequate maintenance infrastructure or management in general can result in a serious threat to the underground environment and speleotourism development (Cigna, 1993). The study of cave conservation in relation to tourism is not simple, since many factors and variables must be simultaneously taken into account.

Modern speleotourism development in Serbia was initiated in the year 1959. The first cave that was opened for visitors was Lazar cave, near the city of Bor in eastern Serbia. For a period of thirteen years this cave was the only tourist cave in Serbia. Further development of speleotourism in Serbia was continued in the year 1972. The second cave that was introduced to the tourism market was Resava cave. A large number of tourists visited the Resava cave during the first year which was completely unexpected and an utter surprise for many people in the tourism industry. This was a powerful incentive for adapting more caves and opening them for tourist visits (Petrović, 2006).

Resava cave is one of the oldest caves in Serbia, located $20 \mathrm{~km}$ from Despotovac (eastern Serbia), in limestone hill called Babina Glava on the bank of the karst field Divljakovac. It is $4.5 \mathrm{~km}$ long, where $2,830 \mathrm{~m}$ have been explored, and a visit can be arranged for only about $800 \mathrm{~m}$. The interior of the cave comprises galleries, canals, poles and jewelery estimated to be 45 million years old. The process of equipping the cave lasted for 10 years, which means that the cave was officially open to visitors on April, 221972 (Lazarević, 1991).

The interests of the local communities involved in the tourism activities should also be considered. The economic importance of geotourism and speleotourism for local communities is adequately presented in the study of Farsani et al. (2011). The authors state that geotourism is an emerging vision that involves the creation of new tourism products, new jobs and new recreational activities. These recreational activities are often related to the topography and geology of the scientific and educational nature, which enables the connection of this type of tourism with school field trips, science camps and other forms of tourism activity (Antić \& Tomić, 2017).

\section{Material and methods}

Research methodology implies a combination of quantitative methods (statistics and Internet analysis) and qualitative methods (written documents). In order to define the theoretical framework of this paper, bibliographic-speculative method was used, and in the processing and interpretation of the results a descriptive method. The survey involved 125 respondents who visited the cave in the month of May, 2018. Questions in the survey included evaluation (on a scale from 1 to 5) of certain speleotourist indicators that affect the comprehensive tourists' experience. These indicators include:

1. Aesthetic values of speleothems;

2. Duration of the tour;

3. State of the pedestrian track; 
4. Lighting and technical equipment;

5. Expertise of the guidance service.

Also, respondents expressed their views on the tourist experience in the cave. They answered positively or negatively about adventurous, excursion, recreational, scientific-educational and cultural tourist experience. The survey was field-based. The author participated in several tours, where he managed to collect 125 completed surveys. For statistical data processing, during the statistical analysis, Microsoft Excel 2010 was used.

An interview with the marketing service of the Resava Cave was also realised. This approach provided additional information that was crucial for understanding tourism business within the geosite. Certain information was obtained, such as the duration of the tours, breaks between the tours, amount of groups that can visit the cave daily and how many visitors can be on a single tour.

\section{Results and discussion}

Social and demographic profile of the respondents is shown in Table 1. It is noticeable that almost the same number of men and women are present among the respondents. Also, $47.2 \%$ of the respondents are married, while $52.8 \%$ are not married.

Table 1: Social and demographic profile of the respondents

\begin{tabular}{|c|c|c|}
\hline 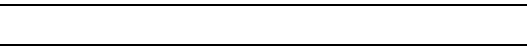 & Number of respondents & Percentage \\
\hline \multicolumn{3}{|c|}{ Sex } \\
\hline Male & 61 & $48.8 \%$ \\
\hline Female & 64 & $51.2 \%$ \\
\hline Total & 125 & $100 \%$ \\
\hline \multicolumn{3}{|c|}{ Family status } \\
\hline Married & 59 & $47.2 \%$ \\
\hline Not married & 66 & $52.8 \%$ \\
\hline Divorced & 0 & $0 \%$ \\
\hline Widow & 0 & $0 \%$ \\
\hline \multicolumn{3}{|c|}{ Age } \\
\hline Less then 15 & 0 & $0 \%$ \\
\hline From 16 to 25 & 39 & $31.2 \%$ \\
\hline From 26 to 35 & 36 & $28.8 \%$ \\
\hline From 36 to 45 & 24 & $19.2 \%$ \\
\hline From 46 to 55 & 11 & $8.8 \%$ \\
\hline Over 55 & 15 & $12 \%$ \\
\hline \multicolumn{3}{|c|}{ Habitation } \\
\hline City (apartment) & 94 & $75.2 \%$ \\
\hline City (house) & 21 & $16.8 \%$ \\
\hline Country place & 10 & $8 \%$ \\
\hline \multicolumn{3}{|c|}{ Profession } \\
\hline Employed & 48 & $38.4 \%$ \\
\hline Unemployed & 14 & $11.2 \%$ \\
\hline Student (University and High School) & 51 & $40.8 \%$ \\
\hline Senior & 12 & $9.6 \%$ \\
\hline \multicolumn{3}{|c|}{ Education } \\
\hline High school & 65 & $52 \%$ \\
\hline Bachelor degree & 53 & $42.4 \%$ \\
\hline $\mathrm{Mr} / \mathrm{Dr}$ & 7 & $5.6 \%$ \\
\hline
\end{tabular}

Source: Research by author 
As for age structure, there is a large number of younger people, but there were also older people among the respondents. The vast majority of respondents live in cities, they are employed and well educated. The data on the number of students among the respondents is revelatory. A total of $51(40.8 \%)$ respondents were students. This fact highlights a great interest of the younger educated population for caves, which is positive information for speleologists and karst enthusiasts, as well as for tourist workers.

Aesthetic values of speleotems are the main cave values and, as such, they are the most significant for the entire tourist experience in the cave. These values include cave jewelry, figures, canals and other diverse geomorphological processes. Statistical analysis of aesthetic values is shown in Figure 1. When respondents evaluated this speleotourist indicator, the rates were mostly positive. A total of 91 respondents rated these values with 5 . A small number of respondents rated these values with 4 and 3 , while no respondents rated these values with 2 or 1 . These results indicate the presence of great interest in geomorphological processes within the cave. This means that the cave holds exceptional aesthetic values. Therefore, there is a great basis for further development of tourism.

Figure 1: Aesthetic values of speleothems

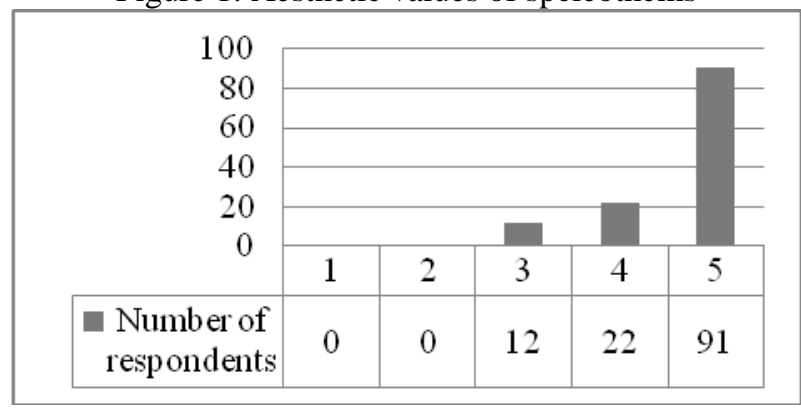

Source: Research by author

The length of the tour is important because some tourists may find this type of tourist engagement to be difficult or exhausting. This speleotourst indicator was also rated highly by the respondents. Statistical analysis of tour duration is shown in Figure 2. A total of 87 respondents rated this indicator with 5 , whereas 27 rated with 4 and 11 with 3 . The duration of the tour in the Resava cave is, therefore, at a satisfactory level. This data points to another positive aspect of the tourism potential of the Resava cave.

Figure 2: Duration of the tour

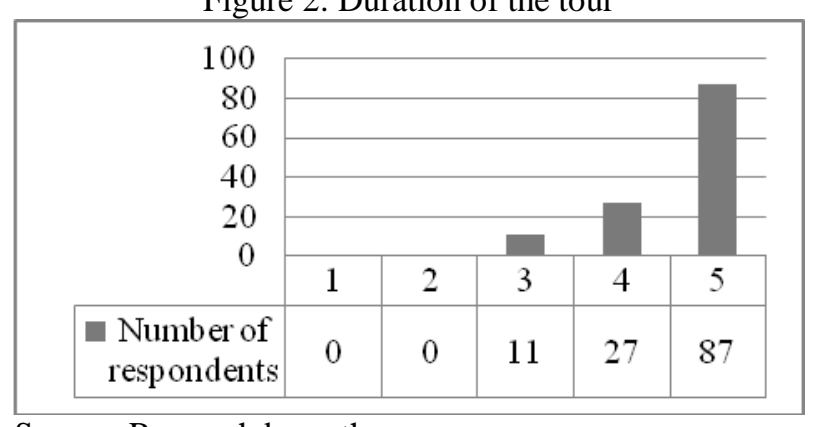

Source: Research by author

The state of the pedestrian track in the cave is the basic infrastructural element, which enables the tourist flow within the cave. Tourists's opinion of this indicator is important because the unfavorable condition of the pedestrian track can affect their safety. In some cases, caves are visited by families with many children. Children also go to caves with 
schools for the educational purposes. Given that children can sometimes be careless, the unfavorable condition of the pedestrian track can jeopardise their safety. Therefore, the safety of tourists should be the starting point when it comes to adjusting the cave for tourist flow. The statistical results of this indicator are shown in Figure 3. In the case of Resava Cave, respondents mostly rated this speleotourist indicator with 5 (76 respondents), while 30 respondents rated this indicator with 4, and 13 with 3. Also, 6 respondents rated this indicator with 2. Some of the weaker grades are given to this indicator. It is assumed that this is because of the lack of handrails in some places in the cave. In general, it can be concluded that this indicator is also positively assessed.

Figure 3: State of the pedestrian track

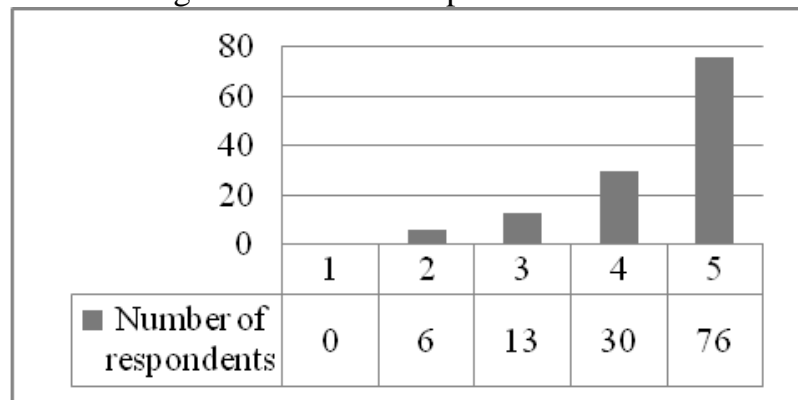

Source: Research by author

As for the lighting and technical equipment in the cave, the tourists were very clear. This indicator was rated 5 by the total of 111 respondents. Figure 4 also shows that 14 respondents rated this indicator with 4 , while no one rated this indicator with lower grades. Technical equipment and lighting of good quality in the cave represent crucial aspects for the development of speleoturism. All the aesthetic values found in the cave should be illuminated in an adequate way so as to be visible to visitors. Positively evaluated, these values indicate the existence of good infrastructure conditions inside the Resava Cave, which can improve and modernise speleotourism.

Figure 4: Lighting and technical equipment

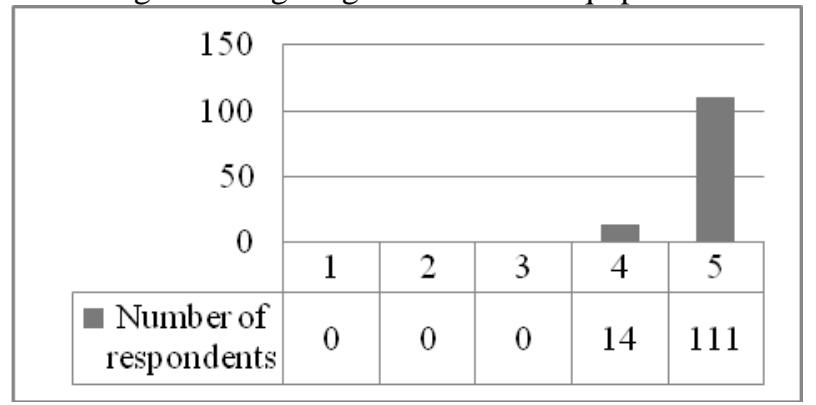

Source: Research by author

The anthropogenic factor of every form of tourism is the most important one. This stems from the fact that the basis for the development of tourism is primarily a human resource. Tourist presentation and guides service form the tourist's experience. This is important because the general impression and experience of tourists is something that affects the general picture of tourist sites. If visitors experience a negative situation, there is little chance that they will return to that place or recommend someone to come. The results of statistical analysis for the speleotourist indicator - Expertise of the guidance service are presented in Figure 5. A total of 102 respondents rated this indicator with 5, only 17 responded with 4 and six respondents with the grade 3 . This means that tour guides and information service 66 
workers have done their job well, which points to another positive aspect of the successful development of speleoturism.

Figure 5: Expertise of the guidance service

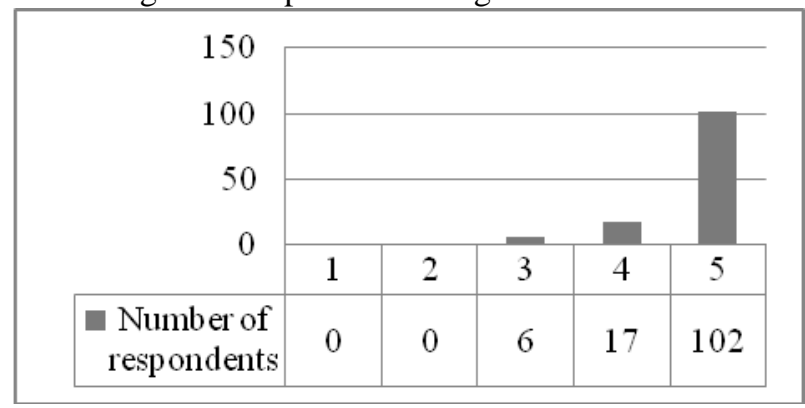

Source: Research by author

The last questions in the survey focused on the experience that tourists had while visiting the Resava Cave. Respondents were offered five tourism experiences: adventurous, excursion, recreational, scientific-educational and cultural. The results are shown in Figure 6. It is noted that the excursion experiences are the most present, while cultural experiences are the least present. Also, adventurous and scientific-educational experiences are highly present. Over 100 respondents indicated that they had an excursion, adventure and scientific-educational experience during their visit to Resava Cave. Fewer tourists had recreational and cultural experience. Therefore, it is concluded that tourists recognise adventure and education in the form of excursions while visiting the cave. These data indicate that tourists are willing to accept speleotourism flow in this region. It is possible that the tourists would visit more caves or other karst areas in one day.

Figure 6: Tourists' experience in Resava cave

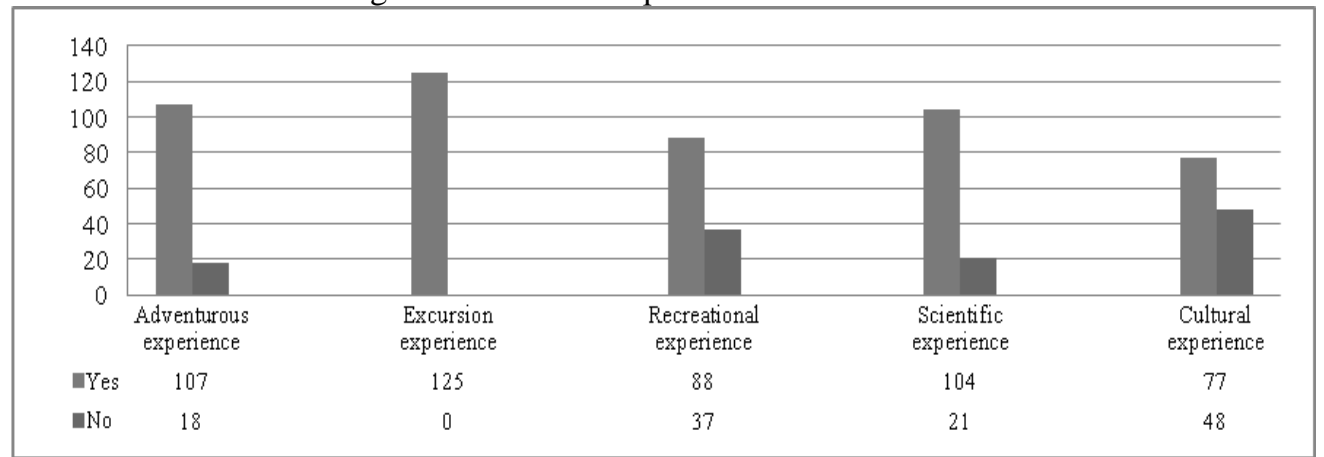

Source: Research by author

The field research also included an interview with the marketing service of Resava Cave. From the interview, a number of useful information was provided which helped to analyse tourism activity in more detail. We learned from the interview that the tours usually last from 30 to 45 minutes, depending on the size of the group. The entrance to the cave is organised every 15 minutes regardless of whether it is a working day or a weekend. The working hours of the cave are from 9 am to 5 pm every day and longer, if necessary. After working hours, there is a guard who also introduces visitors to the cave. During the season, which begins on April 1 and lasts until the end of October, the working hours are extended to 20 hours. Since tours are organised every 15 minutes, the maximum number of daily trips is 32 , or more, when working hours are prolonged. At least one person is required to form a group, and the maximum is 60 . 


\section{Conclusion}

In conclusion, it can be said that Resava Cave is one of the most developed caves in Serbia. It is of national significance and the nucleus of speleotourism and geotourism in eastern Serbia, which can be the initiator of the development of speleoturism in that region. Research has shown that speleotourist indicators positively influence all aspects of the development of speleoturism in the Resava cave. In this regard, the technical equipment and lightning quality should be emphasised as the most important indicator, as it is estimated by respondents to be exquisite. Speleotourist indicators that are also recognised as exceptional by the respondents are the aesthetic values and the expertise of the service guide. Regarding the experience that the tourists had during the tour, it should be noted that the most common one is the excursion experience with the motives of adventure and science.

When it comes to the promotion, Resava Cave has a very organized marketing program. The promotion of the cave includes promotional activities mainly by local and regional tourist organisations. However, this cave is also quite well known on the national level. If we take a look at the annual number of organised visits, we can notice a significant difference between Resava cave and other caves in Serbia. Resava cave has more than 48 organised visits per year while, for example, Ceremošnja Cave currently has no organised tours. When it comes to tourist infrastructure, interpretive panels and tour guide service, Resava Cave's value is the highest. These services and facilities are non-existent or at a much lower level at other speleological geosites. One more major factor is the vicinity of visitor centres. Visitor centre in Resava Cave provides tourists with information about the site or area they are visiting through video displays and exhibitions. Although Resava Cave is one of the most developed tourist destinations for speleotourism, it is always necessary to continually monitor speleotourism trends throughout the world so that Resava cave can be competitive on the market. The uniqueness of this cave certainly provides a possibility for its recognition on the global speleotourism market (Tomić et al., 2018). Tourism potential represents a great value of the Resava cave and it is necessary to modernise continuously all tourist indicators in order to place this geosite on the high position of the global speleotourist market.

\section{References}

1. Anderson, J. (2010). Caves and karst geotourism in Australia. In R. Dowling \& Newsome D. (Eds.), Global Geotourism Perspectives (pp. 49-66). Oxford: Goodfellow Publishers Ltd.

2. Antić, A., \& Tomić, N. (2017). Geoheritage and geotourism potential of the Homolje area (eastern Serbia). Acta Geoturistica, 8(2), 67-78. https://doi.org/10.1515/agta2017-0007

3. Cardozo Moreira, J., \& Neto de Carvalho, C. (2013). Worldwide speleotourism: approaches for economic and heritage sustainability. Tourism and Karst Areas, 6(1), 4-8.

4. Cigna, A. (1993). Environmental management of tourist caves: the examples of Grotta di Castellana and Grotta Grande del Vento, Italy. Environmental Geology, 21, 173-180. https://doi.org/10.1007/BF00775302

5. Dowling, R. K. (2013). Global Geotourism - An Emerging Form of Sustainable Tourism. Czech Journal of Tourism, 2(2), 59-79. https://doi.org/10.2478/cjot-2013$\underline{0004}$

6. Farsani, N.T., Coelho, C., \& Costa, C. (2011). Geotourism and geoparks as novel strategies for socio-economic development in rural areas. International Journal of Tourism Research, 13(1), 68-81. https://doi.org/10.1002/jtr.800 
7. Gams, I. (2003). Kras v Sloveniji v prostoru in času [Karst in Slovenia in space and time ]. Ljubljana: Založba ZRC, ZRC SAZU.

8. Knežević, R., \& Grbac-Žiković, R. (2011). Analysis of the condition and development opportunities of cave tourism in Primorsko-Goranska County. Turizam, 15(1), 11-25. https://doi.org/10.5937/Turizam1101011K

9. Lazarević, R. (1991). Rezultati mikroklimatskih merenja u Resavskoj pećini [Results of microclimate measurements in Resavska cave]. Zaštita prirode, 43-44, 57-79. https://doi.org/15308/Synthesis-2015-552-557

10. Lobo, H. A. S., Trajano, E., de Alcântara Marinho, M., Bichuette, M. E., Scaleante, J. A. B., Scaleante, O. A. F., ... \& Laterza, F. V. (2013). Projection of tourist scenarios onto fragility maps: Framework for determination of provisional tourist carrying capacity in a Brazilian show cave. Tourism Management, 35, 234-243. https://doi.org/10.1016/j.tourman.2012.07.008

11. National Caves Association (2018). Retrieved August 28, 2018 from http:// www.cavern.com

12. Petrović, A. (2006). Speleotourism in Serbia: Condition and development perspectives. Zbornik radova-Geografski fakultet Univerziteta u Beogradu, 54, 183 194. https://doi.org/338.483.11:551.44(497.11)

13. Pulido-Bosch, A., Martin-Rosales, W., López-Chicano, M., Rodriguez-Navarro, C. M., \& Vallejos, A. (1997). Human impact in a tourist karstic cave (Aracena, Spain). Environmental Geology, 31(3-4), 142-149. https://doi.org/10.1007/s002540050173

14. Tomić, N., Antić, A., Marković, S. B., Đorđević, T., Zorn, M., \& Valjavec, M. B. (2018). Exploring the Potential for Speleotourism Development in Eastern Serbia. Geoheritage, 1-11. https://doi.org/10.1007/s12371-018-0288-X

15. Williams, P. (2008). World heritage caves and karst. International Union for Conservation of Nature, Gland, 57. 